\title{
Organization of Management Accounting in Water Transportation Companies
}

\author{
Neizvestnaya D. V. ${ }^{1} \&$ Antonova N. V. ${ }^{2}$ \\ ${ }^{1}$ Kazan Federal University, Institute of Management, Economics and Finance, Kazan, 420008, Russia \\ ${ }^{2}$ Kazan Federal University, Kazan, 420008, Russia \\ Correspondence: Neizvestnaya D. V., Kazan Federal University, Institute of Management, Economics and \\ Finance, Kazan, 420008, Russia.
}

Received: March 19, 2015 Accepted: March 31, 2015 Online Published: April 30, 2015

doi:10.5539/ass.v11n11p330 URL: http://dx.doi.org/10.5539/ass.v11n11p330

\begin{abstract}
The study is to evaluate critically the existing accounting practices in river transportation companies. The authors demonstrate the need for management accounting in inland shipping companies aimed at scheduling, supervising and analyzing their performance and offer a management accounting scheme based on E. Schwarz method. The proposed method of integrated cost system has the following advantages: it takes into consideration the peculiarities of water transportation companies; it is able to collect information on the expenses incurred by areas of responsibility; the system makes it possible to reveal any deviations from the plan and take appropriate measures, which makes company management more efficient.
\end{abstract}

Keywords: water transport, management accounting, cost accounts, budgeting, responsibility centers, segment.

\section{Introduction}

Among the most urgent management accounting, control and analysis targets for all sectors of national economy in general and water transport in particular, are the following: to form new systems to obtain information on production expenditures and financial performance; to introduce efficient management schemes; to increase the importance of information for management.

The task can be solved by creating an adequate accounting system as the principal source of information for both internal and external users. Accounting methodology primarily aims to establish accounting systems in accordance with the company's daily activities, i.e. recording, correlation, and analytic transformation of planned (budget) data and actual amount incurred on financial accounts.

The accounting problem which needs studying is that of accounting and analytical support to budgeting using financial accounts or methods to reflect departure of actual amount incurred from the budget by responsibility centers. By analyzing global and national practices in accounting management using budgeting principles we can conclude that the most appropriate accounting system for water transportation companies is that of creating a separate account for target costs for each responsibility centre and another one for accounting differences revealed between the actual amount incurred and the budget (Carrascal \& Fernández, 2015; Bromiley, McShane, Nair, \& Rustambekov, 2014; Cooper, 2014; Anthony, 1965; Berry, Capps, Cooper, Ferguson, Hopper, \& Lowe, 1985; Anessi-Pessina \& Steccolini, 2007; Simenko \& Kondrashov, 2014; Anthony \& Govindarajan, 2007; Petrenko, 2010; Christensen, 2013; Martins, 2013; Barros, 2005).

\section{Method}

We developed our method to manage expenditures on interlocking accounts on the bedrock of the theory proposed by E. Schwarz. The theory suggests creating an internal (management) accounting scheme aimed to manage inner objects, such as cost elements, responsibility centers' expenditures, business activities, production (services) prime cost (Schwarz, 2001).

This method is of particular interest for water transportation companies. This scheme makes it possible to control labour force, physical and other resources in each responsibility center, which is of utmost importance considering the remote place of expenditures in inland navigation. The integrated financial and management accounting scheme to manage water transportation companies in accordance with the proposed methods is presented in Table 1. 
Table 1. Integrated financial and management cost accounting scheme to manage water transportation companies

\begin{tabular}{|c|c|c|c|}
\hline Account class and details & $\begin{array}{l}\text { Account } \\
\text { number }\end{array}$ & Account details & $\begin{array}{c}\text { Account } \\
\text { type }\end{array}$ \\
\hline \multirow{4}{*}{$\begin{array}{c}\text { Class } 0 \\
\text { "Balance sheet accounts" }\end{array}$} & $0-1$ & Material assets & \multirow{8}{*}{ 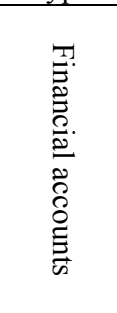 } \\
\hline & $0-2$ & Unfinished production & \\
\hline & $0-3$ & Finished goods on stock & \\
\hline & $0-4$ & Trade debtors & \\
\hline \multirow{4}{*}{$\begin{array}{c}\text { Class } 1 \\
\text { "Resources consumption accounts } \\
\text { (by items)" }\end{array}$} & $1-1$ & Salaries and wages, including free meals & \\
\hline & $1-2$ & Materials & \\
\hline & $1-3$ & Amortization & \\
\hline & $1-4$ & Other expenses & \\
\hline \multirow{5}{*}{$\begin{array}{l}\text { Class } 2 \\
\text { "Reflective accounts (by cost } \\
\text { items) " }\end{array}$} & $2-1$ & Salaries and wages, including free meals & \multirow{9}{*}{ 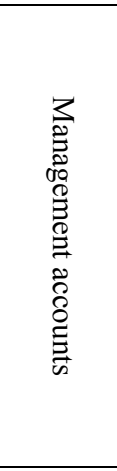 } \\
\hline & $2-2$ & Material expenditures & \\
\hline & $2-3$ & Amortization & \\
\hline & $2-4$ & Other expenses & \\
\hline & $2-5$ & Cost of goods sold & \\
\hline \multirow{4}{*}{$\begin{array}{c}\text { Class } 3 \\
\text { "Cost accounts by responsibility } \\
\text { centers" }\end{array}$} & $3-1$ & $\begin{array}{l}\text { Basic expenditures by principle departments (cargo and } \\
\text { passenger ships, aggregate extraction vessels) }\end{array}$ & \\
\hline & $3-2$ & $\begin{array}{l}\text { Supply ships' expenditures (harbor and engineering } \\
\text { ships, ship's tenders) }\end{array}$ & \\
\hline & $3-3$ & $\begin{array}{l}\text { Auxiliary production departments' expenditures (repair } \\
\text { stations, shipping department) }\end{array}$ & \\
\hline & $3-4$ & Administrative departments' expenditures & \\
\hline \multirow{4}{*}{$\begin{array}{l}\text { Class } 4 \text { "Reflective accounts by } \\
\text { responsibility centers" }\end{array}$} & $4-1$ & Basic unit expenditures & \multirow{25}{*}{ 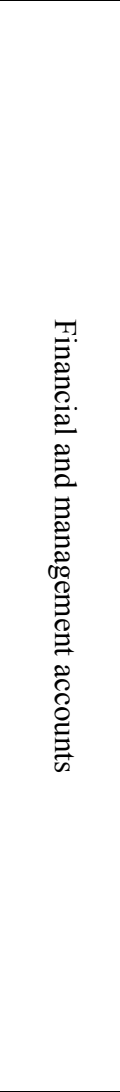 } \\
\hline & $4-2$ & Supply ships expenditures & \\
\hline & $4-3$ & Auxiliary production departments expenditures & \\
\hline & $4-4$ & Administrative department expenditures & \\
\hline \multirow{10}{*}{$\begin{array}{l}\text { Class } 6 \text { "Reflective cost accounts } \\
\text { for certain goods/services" }\end{array}$} & $5-1$ & Passenger transportation & \\
\hline & $5-2$ & Cargo traffic & \\
\hline & $5-3$ & Cargo handling & \\
\hline & $5-4$ & Aggregates & \\
\hline & $5-5$ & Other services & \\
\hline & $6-1$ & Passenger transportation & \\
\hline & $6-2$ & Cargo traffic & \\
\hline & $6-3$ & Cargo handling & \\
\hline & $6-4$ & Aggregates & \\
\hline & $6-5$ & Other services & \\
\hline \multirow{3}{*}{$\begin{array}{l}\text { Class } 7 \\
\text { "Productions cost accounts for } \\
\text { finished and sold goods/services" }\end{array}$} & $7-1$ & Prime cost of finished goods (normally, aggregates) & \\
\hline & $7-2$ & Prime cost of goods sold (normally, aggregates) & \\
\hline & $7-3$ & Prime cost of services rendered & \\
\hline \multirow{4}{*}{$\begin{array}{l}\text { Class } 8 \\
\text { "Sales" }\end{array}$} & $8-1$ & Passenger transportation & \\
\hline & $8-2$ & Cargo traffic & \\
\hline & $8-3$ & Cargo handling & \\
\hline & $8-4$ & Aggregates & \\
\hline \multirow{4}{*}{$\begin{array}{c}\text { Class } 9 \\
\text { "Performance analysis account" }\end{array}$} & $9-1$ & $\begin{array}{l}\text { Differences between resource consumption accounts in } \\
\text { financial accounting and cost accounts (by elements) in } \\
\text { management accounting }\end{array}$ & \\
\hline & $9-2$ & Deviations in organization units & \\
\hline & $9-3$ & Operating profits/losses & \\
\hline & $9-4$ & Deviations from the budget by responsibility centers & \\
\hline \multirow{4}{*}{$\begin{array}{l}\text { Class B } \\
\text { "Budget expenditure accounts by } \\
\text { responsibility centers" }\end{array}$} & B-1 & Principle departments' expenditure budget & \multirow{4}{*}{ 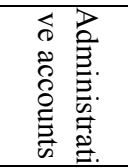 } \\
\hline & B-2 & Supply ships' expenditure budget & \\
\hline & B-3 & Auxiliary production departments' expenditure budget & \\
\hline & B-4 & Administrative departments' expenditures & \\
\hline
\end{tabular}

According to the proposed method business accounts are divided into 11 classes (Classes 0-9 and Class B). Class 1 (financial accounts), Classes 2-7, and B (management accounts) have no closing balance and are directly associated with business expenditures and assets, which are eventually reflected on the accounting balance sheet and income statement. 
Basic principles of implementation of the proposed methods are the following:

1. Creating several accounts for indirect costs instead of one for direct costs:

- Direct and indirect costs by items (class 2),

- Expenditures by responsibility centers (class 2 and class 4). Classes 3 and 4 accounts' itemization can be conducted depending on the company size and structure. For large businesses, for instance, management accounting can be divided into accounting by responsibility centers on the first level of subaccounts, and by vessels (for the core business) and departments (for administrative departments) on the second. For small businesses it suffices to reflect each vessel's and department's expenditures on the first level of subaccounts.

- Expenditures by sorts of goods (services) (classes 5 and 6). There are also several levels. On the first level they are divided by activities (cargo traffic, passenger transportation, cargo handling, aggregate extraction), and on the second level - by specific transportations and types of aggregates.

2. Use of so called "reflective cost accounts" (class 2, class 4, class 6). Class 2 accounts are reflective with regard to class 1 accounts, class 4 accounts correspond to class 3, and class 6 accounts are reflective with respect to class 5. During the accounting period the records are made in accordance with the reflective accounts' credit. At the end of the month, while preparing income statements, all the accounts indicated above are closed by transferring the costs to either class 0 (if there are any assets available) or class 9 accounts. It is worth noting that introduction of reflective cost accounts makes it possible to conduct management accounting according to a specific scheme different form financial accounting.

3. Possibility to implement standard cost system elements. Credit on class 6 reflective cost accounts (equivalent to credit turnover account 20 "core business") is defined as a difference between production output and standard rates of the corresponding expenditures. Therefore, according to the presented method instead of taking inventory, we can assess the amount of unfinished production by calculating the difference between production expenditures in the accounting period and the prime cost of goods sold. This scheme can be implemented for inland shipping companies in aggregate extraction and marketing and will help reveal more exact real value of unfinished production (unsold goods). The existing in extractive enterprises practice to assess value of unfinished product by taking inventory is not effective to control the amount of extracted and sold aggregates because of inaccuracy in measurements and possible errors in recording the amount of mineral sold.

4. Possibility to reflect both factual and planned expenditures by responsibility centers on management accounts (Class B accounts) and subsequently reveal and report the deviations in order to control and analyze the department's activities. This approach allows us to control the efficiency of expenditures and promptly eliminate the identified problems in industrial activities.

\section{Result}

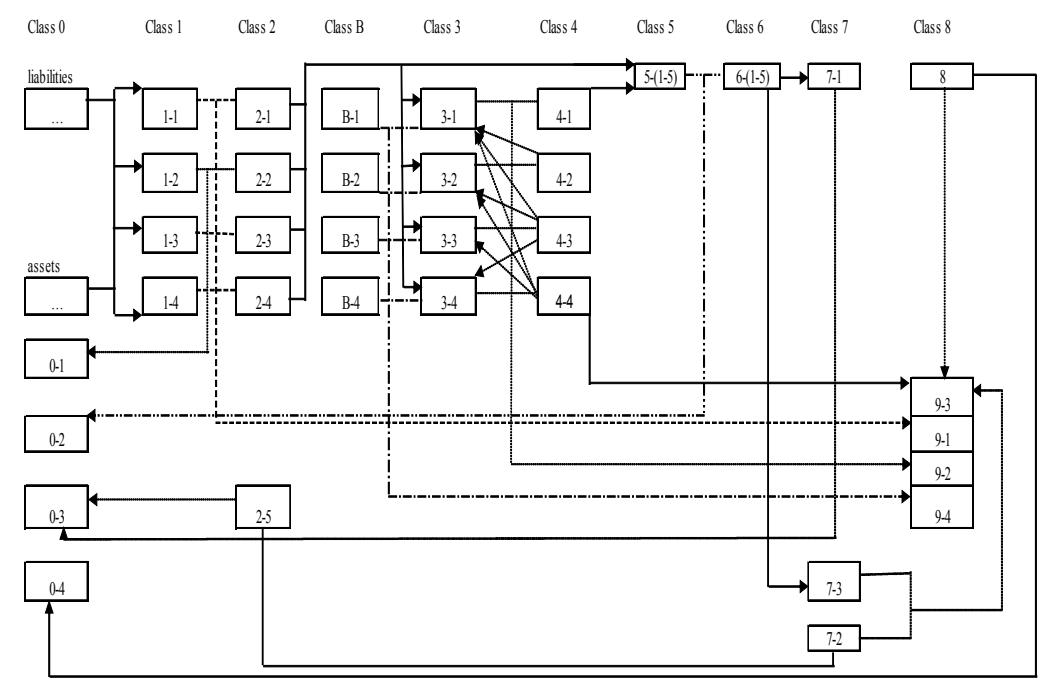

Continuous lines are used for systematic records over the whole period

Dashed lines are used for the records made at the end of the period when closing the accounts.

Figure 1. Cash flow diagram: bookkeeping accounts of water transportation companies 
The proposed scheme for accounting costs on business accounts in river transportation companies is presented in Figure 1. The provided diagram is a generalized model which can be transformed for specific enterprises (lacking some of the activities or departments).

The suggested accounting system offers two methods for recording direct expenditures (Figure 2).

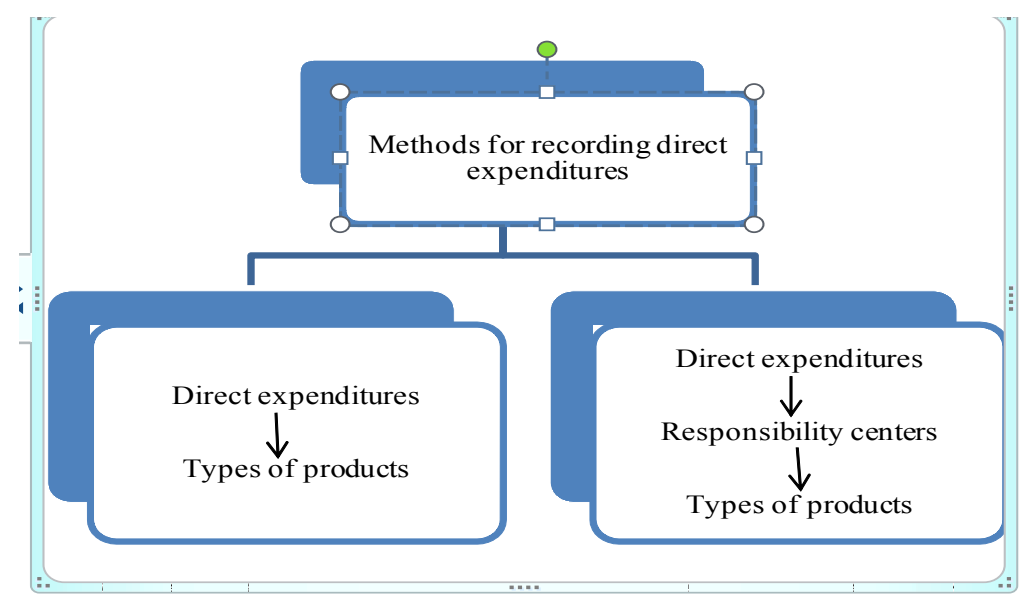

Figure 2. Methods for recording direct expenditures

The first method: class 2 direct expenditures (marine fuel, oils, shipboard personnel salaries, etc.) are directly related to expenses on certain products and services (class 5 accounts), such as specific passenger and cargo ship voyages, some sorts of aggregates.

The second method: direct expenditures which can be accumulated in a certain department are not related to the products or services immediately, but through responsibility centers' accounts, i.e. class 2 accounts, such as material costs, labour costs, are credited to class 3 accounts' debit.

Such an approach promotes organization of an efficient system to control actual and planned (budget) expenditures in the framework of responsibility centers.

Indirect expenses from class 2 accounts are assigned to responsibility centers' or departments' cost accounts, i.e. class 3 accounts.

Expenditures from auxiliary departments are redistributed among responsibility centers which utilized the services. For instance auxiliary departments' expenditures (maintenance, shipping etc.) are distributed among the principle department's expenditures by charging the amount to the accounts 4-3 (debit of account 3-1), management departments' expenditures (debit of account 3-4) and other auxiliary departments' expenditures (debit of account 3-3). Supply ships' expenditures are distributed among principal ships (passenger and cargo) in the following manner: debit of account 3-1, credit of account 4-2. Expenses accumulated in management departments may be assigned to either core business (using full costs method) or directly to sales accounts (for the method of reduced prime cost). The first option enters debit of account 3-1, credit of account 4-4, the second enters debit of account 9-3, credit of account 4-4.

The expenses collected by responsibility centers are distributed from credit of reflective account 4-1 between certain services (goods) to debit of class 5 accounts. For river transportation companies these may include passenger transportation, cargo traffic, cargo handling, aggregates, etc.

Class 6 reflective accounts correspond to class 7 accounts which identify prime cost of the services rendered, finished commodities, and later on, goods sold. According to the provided accounting scheme reflective service cost accounts correspond to account 7-3 "Prime cost of services rendered" and the reflective cost account (for aggregates) corresponds to account 7-1 "Prime cost of finished goods". Class 7 accounts are necessary to correlate with inventory accounts.

At the end of the month the accounts are closed and key accounts are compared with reflective accounts. The difference between credit of class 2 inventory accounts (materials) and debit of class 1 inventory accounts is the balance of account 0-1 "Material assets". To present this information in financial statements it is necessary to charge the sum from debit of account 1-2 to debit of account 0-1; debit the sum from credit of account 2-2 to credit of account $0-1$. The difference on account $0-1$ is the balance of "Material assets" account. In the same way 
we can close classes 1 and 2 non inventory accounts. These are salary costs, amortization and other expenses. These accounts are charged to account 9-1 instead of 0 class accounts.

The difference between credit turnover of class 6 accounts and debit turnover of class 5 accounts is the unfinished production. The amount of expenses from debit of class 5 accounts is charged from the credit of these accounts to debit of account 0-2 "Unfinished production", the expenses from credits of class 6 accounts are charged to credit of account 0-2. The balance on account 0-2 is the account balance of unfinished production.

To calculate prime cost of finished commodities we enter debit 7-1, credit 6 . Credit turnover on account 2-5 "Cost of goods sold" is debited to account 0-3 "Finished goods on stock". Debit of account 7-1 "Prime cost of finished goods" is charged to debit of account $0-3$. Thus we can assess the value of unsold goods.

The following record reflects the total amount of earnings: debit of account 0-4 "Trade debtors" credit of account 8 "Sales".

To find prime cost of goods sold (services rendered) we should enter debit 7-1 (7-3) credit 2-5.

To assess financial result account 8 is debited to credit of account 9-3, and 7-2, 7-3, 4-4 accounts are credited to debit of account 9-3. The balance on account 9-3 is the financial result of the company's primary activity over the period.

The departments' cost accounts (classes 3 and 4) are charged to account 9-2. Balance on account 9-2 indicates either problems in assigning product (service) cost or an error.

Correlation between budget accounts and actual expenditures of responsibility centers is reflected on account 9-4. We must add that in this case the principle differs from the one we employed for reflective accounts. Reporting planned expenses on Class B accounts we used the method of simple recording, these expenses are reported in accordance with debit of class B accounts by responsibility centers and cost elements. As factual expenses appear on class 3 accounts the deviations become visible. Debit of account 9-4 reflects over-expenditure, credit of this account reflects cost saving. Introducing reflective accounts for recording difference between actual planned expenditures by responsible centers allows the management team to take timely measures. At the end of the month balances on class B and 9-4 accounts zero out.

It is recommended to introduce the method proposed above using advanced accounting software programmes by either upgrading the existing accounting programmes or developing special accounting software for bookkeeping and budgeting.

\section{Conclusion}

The method for integrated accounting proposed in this study has the following advantages:

1. This system takes into consideration characteristic features of water transportation companies;

2. The scheme makes it possible to prepare information on the expenses incurred by responsibility centers;

3. It allows us to reveal any departures from the plan and take relevant actions, thus making company management more efficient.

What is more, correspondence between management and financial accounts makes this scheme more convenient, as it allows multiple users to enter data into the accounting system simultaneously.

\section{References}

Anessi-Pessina, E., \& Steccolini, I. (2007). Financial Accountability \& Management, 23, 113-131. http://dx.doi.org/10.1111/j.1468-0408.2007.00422.x

Anthony, R. N. (1965). Planning and control systems. Division of Research, Graduate School of Business Administration, Harvard University, Boston.

Anthony, R., \& Govindarajan, V. (2007). Management Control Systems. Chicago: Mc-Graw- Hill IRWIN.

Barros, C. P. (2005). Decomposing growth in Portuguese seaports: A frontier cost approach. Maritime Economics and Logistics, 7(4), 297-315. http://dx.doi.org/10.1057/palgrave.mel.9100140

Berry, A. J., Capps, T., Cooper, D., Ferguson, P., Hopper, T., \& Lowe, E. A. (1985). Management control in an area of the NCB: Rationales of accounting practices in a public enterprise. Accounting, Organizations and Society, 10(1), 3-28. http://dx.doi.org/10.1016/0361-3682(85)90028-5

Bromiley, P., McShane, M., Nair, A., \& Rustambekov, E. (2014). Enterprise Risk Management: Review, Critique, and Research Directions, Long Range Planning, 2014. http://dx.doi.org/10.2139/ssrn.2376261 
Carrascal, I. A., \& Fernández, M. F. (2015). Tourism and income distribution: Evidence from a developed regional economy. Tourism Management, 48, 11-20. http://dx.doi.org/10.1016/j.tourman.2014.10.016

Christensen, M. D. (2013). The executive budget process: An overview. In The Federal Budget Process: An Introduction (pp. 45-63).

Cooper, D. J. (2014). On the intellectual roots of critical accounting: A personal appreciation of Tony Lowe. Critical Perspectives on Accounting, 25(4-5), 287-292. http://dx.doi.org/10.1016/j.cpa.2014.04.001

Martins, A. (2013). Price regulation and cost accounting: The case of the Portuguese seaport sector. International Journal of Law and Management, 55(6), 444-463. http://dx.doi.org/10.1108/IJLMA-08-2012-0030

Nesterov, V. N., \& Neizvestnaya, D. V. (2014). Application of optimization models in prediction of inland water transport organizations' profit. Mediterranean Journal of Social Sciences, 5(24), 160-164. http://dx.doi.org/10.5901/mjss.2014.v5n24p160

Petrenko, S. M. (2010). Internal Control Enterprise Activity and its Information Provision: Theory, Methodology, Organization (Thesis of Doctoral diss.). Kyiv, Ukraine (in Ukr).

Schwarz, E. F. (2001). Internal accounting: advanced presentation of the chart of accounts for managerial cost accounting (p. 128). Authorhouse.

Simenko, I., \& Kondrashov, O. (2014). Conceptual fundamentals of managerial decision making controlling at an enterprise. Economic Annals-XXI, 1-2(2), 40-43.

Sungatullina, L. B. (2014). Application of linear programming in budgeting costs for the compensation of employees. Mediterranean Journal of Social Sciences, 5(24), 388-392. http://dx.doi.org/10.5901/mjss.2014.v5n24p388

\section{Copyrights}

Copyright for this article is retained by the author(s), with first publication rights granted to the journal.

This is an open-access article distributed under the terms and conditions of the Creative Commons Attribution license (http://creativecommons.org/licenses/by/3.0/). 